\title{
Jedinci koně Převalského (Equus przewalskii) ve sbírce Národního musea v Praze (Perissodactyla: Equidae)
}

\author{
Jiří $\operatorname{VOLF}^{1} \&$ Petr BENDA ${ }^{2}$ \\ ${ }^{1}$ Terronská 14, CZ-160 00 Praha 6 \\ ${ }^{2}$ zoologické oddělení, Národní museum, Václavské nám. 68, CZ-115 79 Praha 1 \& katedra zoologie, \\ př́rodovědecká fakulta University Karlovy, Viničná 7, CZ-128 44 Praha 2; petr.benda@nm.cz
}

došlo 12. 12. 2021

Specimens of Equus przewalskii in the collection of the National Museum, Prague, Czech Republic (Perissodactyla: Equidae). A complete list of 50 specimens of the Przewalski's horse (Equus przewalskii) housed in the collection of the National Museum, Prague, is presented. It consists of two complete skeletons, twelve partial skeletons, 20 skins (two of them mounted), and 40 skulls.

Key words. Przewalski's horse, collection material, National Museum in Prague.

Koně Převalského (Equus przewalskii Polâkov, 1881) na sebe dlouhodobě soustřed'ují pozornost odborné i laické veřejnosti, zejména díky popularitě a úspěchu jejich chovu v zoologické zahradě v Praze. Sledovány jsou různé aspekty jejich biologie, anatomie, chovu či reintrodukce. Díky pražskému chovu vznikla také jedna z největších musejních sbírek tohoto druhu na světě, ve sbírce Národního musea v Praze (NMP) je v současné době k disposici 50 sbírkových jedinců koně Převalského.

První soupis musejního materiálu koní Převalského z celkem dvaceti světových institucí pořídil první autor tohoto textu poté, co byl v roce 1959 pověřen vedením mezinárodní Plemenné knihy koní Převalského (Volf 1961). Překvapivě, v NMP byl tehdy nalezen sbírkový materiál jen dvou hřebců (čísla plemenné knihy [SNr] 83 a 97) a v Hippologickém museu ve Slatiňanech tři kusy, velmi cenný pár s hř́ibětem ( $\mathrm{SNr}$ $65,68,120)$. O rok později (1962) proto zoologická zahrada v Praze hodlala předat Národnímu museu tři kadávery (SNr 94, 98, 261) a kủži (SNr 92) a Vysoké škole zemědělské v Praze skelet včetně lebky ( SNr 92; VOLF 1962). Ovšem z tohoto deklarovaného výčtu se ve sbírce NMP ocitla pouze kůže SNr 92 a navíc až jako součást rozsáhlého souboru materiálu obratlovců předaného ze zoo Praha do NMP v roce 1992 (viz HerÁŇ et al. 1992), namísto toho však 17. ledna 1962 dorazil do sbírky NMP kadaver klisny SNr 72 Heluš, uhynulé ve věku 29 rokủ. Ta tak představuje jedince koně Převalského s nejnižším číslem plemenné knihy ( $\mathrm{SNr}$ ) ve sbírce NMP (tab. 1).

Jednoznačný přehled materiálu koní Převalského v NMP je součástí obsáhlé práce publikované až o třicet let později a přinášející zmíněný soupis sbírkového materiálu ze zoo Praha uložený v NMP (HERÁŇ et al. 1992). Ten obsahuje údaje o pěti hřebcích (SNr 76, 83, 97, 120, 583) a dvou klisnách ( $\mathrm{SNr}$ $72,471)$. Vzhledem k tomu, že v té době veškerý evidovaný sbírkový materiál koní Převalského v NMP pocházel z pražské zoo, tento přehled je úplným výčtem tehdejší sbírky. Soupis sbírky NMP, který později pubikovala SPASSKAÂ (2000) není úplný a vykazuje určité nepřesnosti. O deset let později byl uveřejněn seznam osteologického materiálu koní Převalského v NMP, zahrnujícího údaje o 30 jedincích (VoLF 2010). RовоvSкÝ et al. (2014) publikovali obsáhlý a ucelený katalog koňovitých lichokopytníků sbírky NMP, v němž jsou koně Převalského zastoupeni 39 jedinci. Katalog je úplný až na vynechaného jedince 
Tab. 1. Sbírkový materiál koní Převalského (Equus przewalskii) v Národním muzeu v Praze. Jedinci jsou řazeni podle číslování v Mezinárodní plemenné knize koně Převalského ( $\mathrm{SNr}$ ), nikoliv podle evidenčních čísel Národního musea, nebot' ta nepředstavují chronologickou řadu. Vysvětlivky: $\mathrm{SNr}$ - číslo plemenné knihy, NMP - číslo sbírkové evidence Národního musea; prep. - preparace: $\mathrm{S}$ - lebka, $\mathrm{P}$ - neúplná kostra, Sk - úplná kostra, K - kůže (deka), M - kůže (vycpanina); pohl. - pohlaví; věk je uveden v rocích

\begin{tabular}{|c|c|c|c|c|c|c|c|c|c|}
\hline $\mathrm{SNr}$ & NMP & prep. po & pohl. & č. chovu & jméno & narození & úhyn & věk & poznámka \\
\hline 72 & 22772 & $\mathrm{~S}+\mathrm{P}$ & 우 & Praha 5 & Heluš & 21.3. 1933 & 10. 1.1962 & 29 & \\
\hline 74 & 47167 & $\mathrm{~S}+\mathrm{K}$ & 우 & Praha 7 & Lucka & 1. 7.1941 & 6.11. 1964 & $23 \frac{1}{2}$ & $\begin{array}{l}\text { červený } \\
\text { bělouš }\end{array}$ \\
\hline 76 & 24688 & $\mathrm{~S}+\mathrm{M}$ & $\sigma^{\lambda}$ & Praha 9 & Uran & 27. 5. 1944 & 11. 7. 1974 & 30 & \\
\hline 78 & 52908 & K & $\delta$ & Praha 11 & Oskar & 4. 7.1950 & 5. 6.1967 & 17 & \\
\hline 83 & 10649 & $\mathrm{~S}+\mathrm{P}+\mathrm{K}$ & 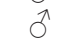 & Praha 16 & Ajak & 18. 5. 1953 & 15.9. 1957 & $4 \frac{1}{2}$ & \\
\hline 86 & 57189 & $\mathrm{~K}$ & 우 & Praha 19 & Vesna & 17. 5.1954 & 25. 1.1973 & $19^{1 / 2}$ & \\
\hline 92 & 52910 & $\mathrm{~K}$ & $\sigma^{\lambda}$ & Praha 25 & Leo & 5. 5.1957 & 5. 11.1959 & $2 \frac{1}{2}$ & tmavý nos \\
\hline 96 & 47171 & $\mathrm{~S}$ & 우 & Praha 29 & Vida & 14. 6.1958 & 23.6 .1965 & 7 & \\
\hline 97 & 22771 & $\mathrm{~S}+\mathrm{Sk}$ & $\hat{0}$ & Praha 30 & Milan & 26. 6.1958 & 19. 11. 1959 & $1 \frac{1}{2}$ & \\
\hline 120 & 46507 & $\mathrm{P}+\mathrm{K}$ & $\hat{\sigma}$ & Washington 1 & Horymír & 21.6 .1930 & 25. 7.1944 & 14 & \\
\hline 250 & 47165 & $\mathrm{~S}$ & 우 & Praha 39 & Háta & 3. 6.1960 & 17. 5.1982 & 22 & \\
\hline 270 & 47166 & S & 우 & Praha 46 & - & 4. 5.1962 & 7. 5.1962 & 0 & \\
\hline 273 & 47160 & S & 우 & Praha 48 & Hera & 9.5 .1962 & 24.11 .1984 & $22 \frac{1}{2}$ & \\
\hline 291 & 52911 & $\mathrm{~K}$ & $\hat{0}$ & Praha 55 & Vezír & 13. 6.1963 & 13.11 .1965 & $21 / 2$ & tmavý typ \\
\hline 323 & 47162 & S & $\sigma^{\lambda}$ & Praha 66 & Vikomt & 1. 10.1964 & 17. 5.1966 & $1 \frac{1}{2}$ & \\
\hline 337 & 47170 & S & $\hat{\sigma}$ & Praha 73 & Vasal & 9.6 .1965 & 13. 2.1967 & $13 / 4$ & \\
\hline 363 & 47163 & $\mathrm{~S}+\mathrm{K}$ & 우 & Praha 80 & Vlha & 7. 10.1966 & 21. 7.1969 & $23 / 4$ & tmavé břicho \\
\hline 376 & 47168 & $\mathrm{~S}$ & $\hat{0}$ & Praha 84 & Hubert & 3. 6.1967 & 21. 8. 1968 & $1 \frac{1}{4}$ & \\
\hline 395 & 47169 & S & $\sigma^{\lambda}$ & Praha 90 & Vir & 3. 6.1968 & 21. 7.1969 & 1 & \\
\hline 403 & 47173 & $\mathrm{~S}+\mathrm{K}$ & 우 & Praha 94 & Helada & 22. 2. 1969 & 7. 12.1975 & $63 / 4$ & \\
\hline 463 & 52912 & $\mathrm{~K}$ & 우 & Praha 98 & - & 18. 4. 1970 & 25. 4. 1970 & 0 & \\
\hline 471 & 46585 & $\mathrm{~S}+\mathrm{P}+\mathrm{K}$ & 우 & Praha 100 & Artemis & 23. 5. 1970 & 16. 5.1977 & 17 & \\
\hline 481 & 48351 & $\mathrm{~S}+\mathrm{P}$ & 우 & Praha 102 & Afrodite & 7. 8.1970 & 23. 6.1996 & $25^{3 / 4}$ & \\
\hline 488 & 47161 & $\mathrm{~S}$ & 오 & Praha 105 & Balada & 27.4. 1971 & 21.5. 1976 & 5 & \\
\hline 492 & 48756 & $\mathrm{~S}+\mathrm{P}$ & 우 & Praha 106 & Bára & 17. 5.1971 & 1. 5.2000 & 29 & \\
\hline 511 & 15687 & $\mathrm{~S}+\mathrm{K}$ & 우 & Praha 108 & Cilka & 21.3. 1972 & 12. 8. 2006 & $34 \frac{1}{2}$ & $\begin{array}{l}\text { silně deformo- } \\
\text { vaný chrup }\end{array}$ \\
\hline 583 & 22770 & S & o & Praha 115 & Eben & 11. 5.1974 & 23. 8. 1974 & $1 / 2$ & \\
\hline 862 & 57184 & $\mathrm{~K}$ & o & Praha 129 & Juno & 8. 9. 1979 & 1. 5. 1982 & $2 \frac{1}{2}$ & \\
\hline 943 & 96133 & $\mathrm{~K}$ & $\hat{0}$ & Praha 131 & - & 20.1.1981 & 8. 10. 1981 & $3 / 4$ & \\
\hline 1011 & 95180 & $\mathrm{~S}$ & 오 & Praha 132 & Linda & 4. 8.1981 & 25. 6. 2012 & 31 & \\
\hline 1086 & 48198 & $\mathrm{~S}+\mathrm{P}+\mathrm{K}$ & 우 & Praha 133 & Mona & 7. 8.1982 & 1. 12.1998 & $16^{1 / 2}$ & $\begin{array}{l}\text { kůže jen } \\
\text { z hlavy }\end{array}$ \\
\hline 1127 & 90200 & $\mathrm{~S}+\mathrm{P}$ & 우 & Praha 134 & Nora & 16. 5. 1983 & 22.11 .2004 & $21 \frac{1}{2}$ & \\
\hline 1305 & 57176 & K & 우 & Praha 137 & Pavlína & 6.2. 1985 & 22. 4. 1992 & $71 / 4$ & \\
\hline 1325 & 90194 & $\mathrm{~S}+\mathrm{Sk}+\mathrm{M}$ & M $\sigma^{\pi}$ & Midway 13 & Danny Boy & 4. 5.1985 & 3. 9. 2001 & $16^{3 / 4}$ & \\
\hline 1360 & 47164 & S & $\hat{\sigma}$ & Praha 139 & Patrik & 5. 6.1985 & 5. 10. 1988 & $3 \frac{1}{4}$ & \\
\hline 1656 & 96345 & $\mathrm{~S}$ & o & Praha 153 & Roma & 2. 12. 1987 & 13. 12. 2016 & 29 & \\
\hline 2169 & 90195 & $\mathrm{~S}+\mathrm{P}+\mathrm{K}$ & 0 & Bratislava 4 & Martin & 8. 5. 1991 & 6.9.2001 & $10^{1 / 4}$ & \\
\hline 2324 & 96346 & $\mathrm{~S}$ & 0 & Praha 173 & Xeron & 17. 5. 1992 & 21. 5. 2014 & 22 & \\
\hline 2402 & 49009 & $\mathrm{~S}+\mathrm{P}$ & $0^{\lambda}$ & Praha 176 & Xerox & 30. 10. 1992 & 27. 10. 2000 & 8 & \\
\hline 2500 & 48278 & $\mathrm{~S}+\mathrm{P}$ & $0^{\lambda}$ & Praha 184 & Yper & 26. 6. 1993 & 13. 5. 1999 & 6 & \\
\hline
\end{tabular}




\begin{tabular}{|c|c|c|c|c|c|c|c|c|c|}
\hline $\mathrm{SNr}$ & NMP & prep. & pohl. & č. chovu & jméno & narození & úhyn & věk & poznámka \\
\hline 2522 & 96755 & $\mathrm{~S}+\mathrm{P}$ & 우 & Praha 185 & Ycory & 22. 10. 1993 & 20.3. 2016 & $231 / 2$ & \\
\hline 3349 & 96990 & $\mathrm{~S}$ & $\hat{O}$ & Praha 201 & Fucík & 20.10 .2000 & 8. 3. 2015 & $14 \frac{1}{4}$ & \\
\hline 3515 & 40420 & $\mathrm{~S}+\mathrm{K}$ & 우 & Praha 203 & Gaja & 5. 5. 2001 & 8. 11.2012 & $11 \frac{1 / 2}{2}$ & \\
\hline 3563 & 96991 & $\mathrm{~S}$ & $\hat{0}$ & Praha 205 & Garp & 24. 10. 2001 & 22. 12. 2008 & $71 / 4$ & S poškozená \\
\hline 5645 & 96342 & $\mathrm{~S}$ & 우 & Hortobágy & Márta & 5. 6.2010 & 15. 3. 2012 & $13 / 4$ & \\
\hline 5756 & 96754 & $\mathrm{~S}$ & 우 & Hortobágy & Nílus & 5. 5. 2011 & 2. 7.2014 & 3 & \\
\hline 5789 & 96343 & $\mathrm{~S}$ & ㅇ & Hortobágy & Nimfa & 15. 5. 2011 & 14. 1.2014 & $23 / 4$ & \\
\hline 6163 & 96250 & $\mathrm{~S}$ & o & Helsinky & Finnmog & 3. 2.2013 & 7. 1.2015 & 2 & \\
\hline 6172 & 95181 & $\mathrm{~S}$ & $\hat{0}$ & Slatiňany 8 & Octavian & 10.4. 2013 & 2. 6.2014 & 1 & \\
\hline- & 95116 & $\mathrm{~K}$ & 우 & zoo Hamburk & - & & 16. 2.1930 & - & viztext a obr. 1 \\
\hline
\end{tabular}

NMP 40420 (SNr 3515 Gaja) a záměnu dvou SNr (u jedince NMP 95180 by namísto údajů o klisně SNr 1313 Petra měly být údaje o klisně SNr 1011 Linda).

Od té doby došlo k upřesnění údajů o sbírkových jedincích, a především k výraznému doplnění sbírky koní Převalského uložené v NMP; zde je uveden soupis aktualisovaný ke konci roku 2021. Sbírka nyní sestává ze dvou úplných skeletů, dvanácti neúplných postkraniálních skeletů, 21 kůží a 40 úplných či téměř úplných lebek, celkem obsahuje 50 položek/jedinců (tab. 1). První neúplná kostra, která přišla do NMP, patřila zřejmě importovanému hřebci SNr 120 Horymír, uhynulému koncem druhé světové války; jeho lebka je nezvěstná. Nejstarší kůže a vůbec nejstarší sbírková položka koně Převalského ve sbírce NMP (evidovaná ovšem až roku 2014) pochází z klisny zakoupené profesorem F. BíLKem neznámo kdy u Hagenbecka v Hamburku pro tehdejší Vysokou školu zemědělského a lesního inženýrství ČVUT v Praze; v roce 1930, patrně krátce po jejím úhynu, daroval prof. BíleK její kủži NMP protihodnotou za vycpání dvou karakulských ovcí (RoBOvSKÝ et al. 2014; obr. 1). Zcela nedávno prribyly do sbírky NMP lebky koní původem z Národního parku Hortobágy v Mad'arsku a z východočeských Slatiňan (ovšem vše via zoo Praha).

Př́chody chovaných zvírat do musejní sbírky jsou podmíněny především ochotou chovatelů na spolupráci se sbírkou. Nejvíce jedinců koně Převalského ve sbírce NMP pochází z šedesátých let minulého století (11), což odráží tehdejší popularitu divokých koní a rozvoj pražského chovu; podobně plodným obdobím ovšem bylo i to poslední, v letech 2010-2020 přibylo do sbírky NMP také 11 jedinců. Rozložení původu ostatních přírůstků je - dle data úhynu jedince, nikoliv evidence ve sbírce - následující: před rokem 1950: 2 ks, 1950-1959: 3 ks, 1970-1979: 7 ks, 1980-1989: 5 ks, 1990-1999: 4 ks, 2000-2009: 7 ks (ostatní detaily viz tab. 1).

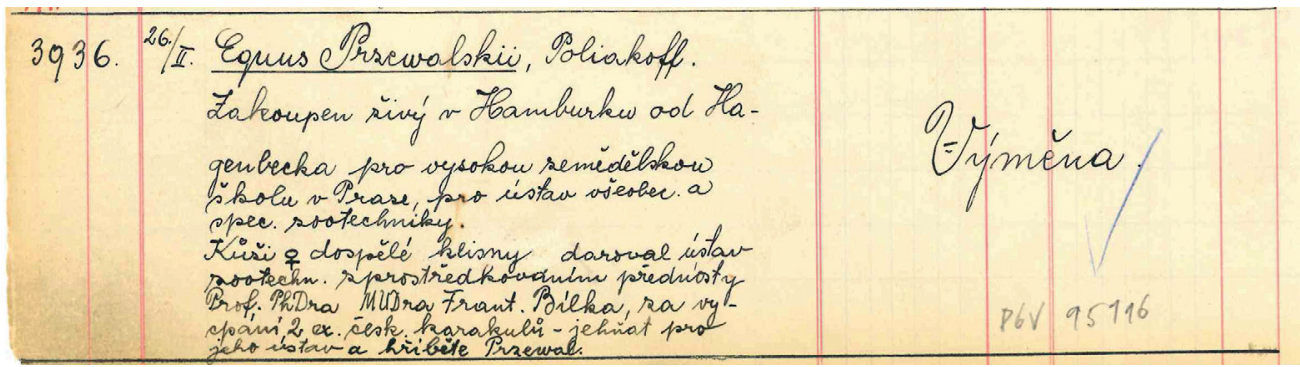

Obr. 1. Zápis v př́růstkové knize zoologického oddělení Národního musea v Praze z 26. února 1930 o prijijetí kủže koně Převalského do sbírky. 
Lebky ve sbírce NMP patř́ jedincům uhynulým v širokém věkovém rozpětí od tř́i dnů (SNr 270) až po senilní věk $\left(34 \frac{1}{2}\right.$ roku; SNr 511 Cilka). Na kolekci tedy mủžeme dobře pozorovat změny v celém postnatálním vývoji lebky včetně dentice; věkové skupiny $1 / 2-2$ roky, $2-5$ let, $5-15$ let a $15-25$ let jsou každá zastoupena ve sbírce nejméně 9 jedinci, věk $0-1 / 2$ roku zastupují 3 kusy, 25-30 let 5 kusů a věkovou kategorii nad 30 let 2 kusy (detaily viz tab. 1).

Dvacet jedna kůží koní Převalského uložených v NMP náleží devíti hřebcům a dvanácti klisnám, z toho dvě hřebčí kůže jsou preparovány jako vycpaniny pro výstavní účely (SNr 76 a 1325). Kůže pocházejí od jedinců uhynulých ve stáŕí 7 dní až 30 let v různých ročních dobách. Poskytují tak možnost poznat rozdíly v kvalitě srsti zvírat z hlediska stáŕí jedinců, klimatických podmínek a typu, včetně barevných odchylek.

Nezvěstný osteologický materiál koní Převalského, jenž má vazbu na NMP, pochází z Hippologického muzea ve Slatiňanech - tam byl roku 1961 prvním autorem zaznamenán, za prítomnosti profesora $\mathrm{F}$. BíLKA, kompletní dokladový materiál (skelet, lebka, kůže) dospělého hřebce SNr 120 Horymír (*1930 Washington, †1944 Praha, sign. Zvl. 48/50), dospělé klisny SNr 65 Minka (*1920 Halle/S, †1932 Praha, sign. Slatiňany 861/862), hř́běte klisničky (SNr 68) narozeného i uhynulého roku 1926 v Netlukách (sign. Zvl. 49, Slatiňany 863). Z hřebce Horymíra se v NMP dochovala kůže, lopatka a dlouhé kosti končetin, materiál ostatních kusů je nezvěstný. Tyto jedince je vhodné zmínit, i když byly všechny původně uloženy mimo NMP, nebot' představují geneticky zajímavé kusy. Uvádíme také jejich originální identifikační čísla pro př́ípad, že by se s nimi badatelé setkali v jiných sbírkách. Nelze ale vyloučit, že tento sbírkový materiál byl v poslední třetině minulého století mimo NMP či Hippologické muzeum “dlouhodobě zapůjčen", např. při řešení otázky čistokrevnosti linií koní Převalského (MAZÁK \& DoBRoRuKa 1967, RYDER et al. 1984) a zůstává nedostupný, at' už úmyslně či omylem.

\section{P o d ě k ová n í}

Děkujeme paní Aleně HoFrichTEROvÉ za poskytnutí informací o jedincích pocházejících ze zoologické zahrady v Praze.

\section{LITERATURA}

HeráŇ I., Hora J. \& MoraveC J., 1992: Materiály obratlovců z pražské zoo, uložené ve sbírkách Národního muzea. Gazella, 19: 119-130.

MAzÁ́ V. \& Dobroruka L. J., 1967: Rekonstruktion des Przewaldskipferdes, eine Grundlage für die negative Selektion in der Prager Urwildpferd-Zucht. Equus, 1(2): 329-349.

Robovský J., Novotná A., Čulík L., Kưs E. \& Benda P., 2014: Revised catalogue of wild equids in the collection of the National Museum, Prague, and several other collections in the Czech Republic (Perissodactyla: Equidae). Lynx, n. s., 45: 97-138.

Ryder O. A., Bowling A. T., Brisbin P. C., Carrol P. M., Gadi I. K., Hansen S. K. \& Wedemeyer E. A., 1984: Genetics of Equus przewalskii Poliakov, 1881: Analysis of genetic variability in breeding lines, comparison of equid DNAs, and a brief description of a cooperative breeding program in North America. Equus, 2(2): 207-227.

SPASSKAÂ N. N., 2000: Issledovanie osteologičeskogo materiala po lošadi Prževal'skogo (Equus przewalskii Poljakov, 1881), hranâŝegosâ v muzeâh Čehii. Gazella, 27: 71-95.

Volf J., 1961: Seznam kadáverů koní Převalského. Pp.: 17-21. In: Volf J. (ed.): Plemenná kniha koní Převalského. Zoologická zahrada Praha, Praha, 24 pp.

VOLF J., 1962: Doplnění a opravy původního seznamu kadáverů koní Převalského. Pp.: 18-22. In: VolF J. (ed.): Plemenná kniha koni Převalského. Zoologická zahrada Praha, Praha, 28 pp.

Volf J., 2010: Osteologický materiál koní Převalského (Equus przewalskii Poljakov, 1881) v Národním muzeu v Praze. Equus, 2010: 57-62. 